\title{
Effects of energy levels and sources on plasma metabolites and live weight of Holstein cows
}

\author{
B.A. Useni ${ }^{1 \#}$, C.J.C. Muller ${ }^{1,2}$ \& C.W. Cruywagen ${ }^{1}$ \\ ${ }^{1}$ Department of Animal Sciences, University of Stellenbosch, Private Bag X1, Matieland 7602, South Africa \\ ${ }^{2}$ Western Cape Department of Agriculture, Research and Technology Development Services, Directorate: Animal \\ Sciences, Private bag X1, Elsenburg 7607, South Africa
}

(Received 15 June 2017; Accepted 22 January 2018; First published online 30 July 2018)

\author{
Copyright resides with the authors in terms of the Creative Commons Attribution 4.0 South African Licence. \\ See: http://creativecommons.org/licenses/by/4.0/za \\ Condition of use: The user may copy, distribute, transmit and adapt the work, but must recognise the authors and the South African \\ Journal of Animal Science.
}

\begin{abstract}
The objective of the study was to evaluate the effects of nutritional treatments, which differed after calving, on energy levels and sources on plasma metabolite profiles and live weight (LW) changes as an indication of the nutritional status in Holstein cows. During the dry period, pregnant heifers $(n=69)$ and dry cows $(n=153)$ from Elsenburg Research Farm were maintained under similar feeding and management conditions. After parturition, cows had ad libitum access to cultivated irrigated kikuyu-ryegrass pastures, and were assigned to three concentrate groups, according to calving date, parity, LW and the milk yield of their previous lactation. The groups were supplemented with various levels and types of concentrate, of which the energy was provided by starch and fat. The control group was offered $7 \mathrm{~kg} / \mathrm{cow} /$ day of a control concentrate supplement for both primiparous and multiparous groups, while concentrates in treatment groups were fed at 11.6 and $12.6 \mathrm{~kg} / \mathrm{cow} / \mathrm{day}$ for primiparous and multiparous groups, respectively. The control supplement was a maize-based concentrate, which contained low levels of starch. The concentrate components of the treatments consisted of high starch-low fat (HSLF) and a high starch-low fat/low starch-high fat (HSLF-LSHF) combination. The HSLF supplement was a glucogenic concentrate, which contained maize as the energy source. The HSLF-LSHF supplements consisted of a glucogenic concentrate, which was offered for the first 60 days in milk (DIM) as per the HSLF treatment, and was followed from 61 DIM with a lipogenic concentrate containing wheat bran and calcium (Ca) salts of long-chain fatty acids as the energy sources. The results showed that all cows mobilized their body fat reserves, as was evident in changes in plasma non-esterified fatty acids (NEFA) before and after calving. Postpartum plasma NEFA and $\beta$-hydroxybutyrate (BHB) did not differ significantly between nutritional treatments in multiparous cows. However, the postpartum levels of plasma NEFA and BHB were significantly higher for the control, indicating a status of advanced negative energy balance (NEB) and possible subclinical ketosis compared with HSLF and HSLF-LSHF treatments in primiparous cows. Postpartum plasma urea levels decreased significantly in both primiparous and multiparous animals in the control group, compared with the HSLF and HSLF-LSHF groups. As affected by time, postpartum LW was significantly lowest and LW loss was significantly highest in cows that received the control supplements compared with HSLF and HSLF-LSHF supplements for primiparous and multiparous cows. In addition, LW loss $_{\text {nadir }}$ and the number of days to reach it significantly increased in primiparous cows that received the control concentrate, compared with those of the HSLF and HSLF- LSHF treatments. However, this trend was not observed for multiparous cows. The findings of this study showed that HSLF and HSLF-LSHF treatments improved the nutritional status, as was evident in the reduced extent of NEB and limited LW loss of dairy cows, compared with those in the control group.
\end{abstract}

Keywords: Concentrate, dairy cattle, energy nutrients, nutritional status, pasture

\# Corresponding author: alainub83@gmail.com

\section{Introduction}

During the transition period, dry matter intake (DMI) does not generally satisfy the increasing nutrient demand of dairy cows, mainly because of a decrease in feed intake and appetite (Walsh et al., 2011). As a result, dairy cows go into a state of NEB and thus mobilize body reserves as a physiological mechanism to adapt to the energy deficiency from late gestation to early lactation (Van Knegsel et al., 2007b; McArt et al., 
2013). NEB starts a few days before parturition, reaching an NEB nadir two to four weeks postpartum, with the energy balance (EB) becoming positive again by 10 to 12 weeks after calving (Butler, 2003). During the NEB period, NEFA are released intensively from adipose tissues and recycled as energy fuels (Adewiyi et al., 2005; Hammon et al., 2009). This strong mobilization of body reserves induces imbalances in fat and carbohydrate metabolism with increases in ketone bodies and tri-acyl glycerol, respectively, leading to subor clinical ketosis (Schulz et al., 2014) and fatty liver syndrome (Drackley et al., 2001). A state of NEB results in the loss of body score condition (BCS) and live weight (LW) (Jorritsma et al., 2003; Van Straten et al., 2008). Measurement of LW is an established method for monitoring the growth performance of livestock such as beef cattle, sheep and broilers. Using LW as a tool to assess EB in dairy cows, however, has been discouraged owing to the possible confounding effects of parity, stage of lactation, frame size, stage of gestation, rumen fill and breed (Alawneh et al., 2012; Thorup et al., 2012). Roche et al. (2009) reported that measurement of postpartum LW does not offer a true reflection of the EB status of an individual cow. This report was correct because in many studies the LW of cows in milk was measured on a cross-sectional basis (i.e. at certain key points in the dairy production cycle, for example milk tests). However, the use of continuous Live weight monitoring on a daily or weekly basis could be an efficient means of monitoring onfarm management-related performances in dairy herds (Sakaguchi, 2009). This technique could estimate EB status by identifying cows that continue to lose or gain weight over time (Jorritsma et al., 2003; Thorup et al., 2013). LW is an easy and fast method to use at farm level, compared with the inherent difficulties with BCS measurement owing to inter-observer inconsistency and bias (Broster \& Broster, 1998; Van Straten et al., 2008). Also, the continuous walkover or walkthrough weighing system at the exit of the milking parlour is non-intrusive and is a relatively accurate tool that could reduce stress on animals. Numerous nutritional approaches have been investigated to improve the plasma metabolite profile and prevent LW loss. Some studies demonstrated that enhancing the postpartum metabolizable energy (ME) intake by reducing the forage-to-concentrate ratio or by supplementing energy-dense ingredients such as dietary starch and fat reduces the extent and the duration of NEB and improves the LW of dairy cows (Drackley et al., 2003; Staples et al., 1998; Voigt et al., 2003; Van Knegsel et al., 2005; Gilmore et al., 2011). The objective of the current study was therefore to investigate the effect of nutritional treatments that differed after calving in energy levels (low versus high) and sources (starch versus fat) on blood metabolite profile and LW changes until 154 days postpartum, and to determine the extent to which these parameters could provide an indication of the postpartum nutritional status and health of Holstein dairy cows.

\section{Materials and Methods}

Ethical clearance for this study was obtained from the Western Cape Department of Agriculture (WCDA, Project AP/BR/D/CM31).

The study was conducted at Elsenburg Research Farm of WCDA, which is located approximately 50 $\mathrm{km}$ east of Cape Town at an altitude of $177 \mathrm{~m}$, longitude $18^{\circ} 50^{\prime}$ and latitude $33^{\circ} 51^{\prime}$ in the winter rainfall region of South Africa. The area receives an average annual rainfall of $650 \mathrm{~mm}$ and has a typical Mediterranean climate with short cool wet winters and long warm dry summers.

Holstein cows in the study were from the Elsenburg herd and had calved from August 2012 to July 2014. Cows were included in the study from four weeks before parturition to 22 weeks postpartum. Fresh drinking water was freely available at all times in the trial. During the dry period of the trial, pregnant heifers and dry cows were maintained in two separated camps under the same feeding and management conditions. Animals were fed unchopped oat hay ad libitum, supplemented with a prepartum concentrate mixture (Table1), containing maize as the main energy source and anionic salts, at $3 \mathrm{~kg} /$ day for heifers and cows from 30 to 14 days prepartum, and thereafter from 13 days prepartum to the calving date, 6 and 5 $\mathrm{kg} / \mathrm{day}$ for cows and heifers, respectively. Following parturition, cows were allocated to three nutritional treatments, based on parity, LW at calving and milk yield during the previous lactation period. Additionally, allocations to nutritional programmes were done strictly in both parity groups, according to calving dates, so that animals were exposed to similar environment conditions during the observation period of the trial. Primiparous animals were assigned based on their LW and calving dates. Live weights of primiparous cows at calving were $502 \pm 14,493 \pm 13$ and $491 \pm 9 \mathrm{~kg}$ for the control, HSLF and HSLF-LSHF groups, respectively. Primiparous cows were $2.22 \pm 0.05,2.18 \pm 0.04$ and $2.27 \pm 0.05$ years old at calving for the control, HSLF and HSLF-LSHF groups, respectively. Multiparous animals were assigned according to parity, previous lactation milk yield and calving dates. Live weights of multiparous cows at calving were $621 \pm 11$, $630 \pm 10$ and $620 \pm 11 \mathrm{~kg}$ for the control, HSLF and HSLF-LSHF groups, respectively. Multiparous cows were $5.35 \pm 0.20,5.11 \pm 0.29$ and $5.15 \pm 0.26$ years old at calving for the control, HSLF and HSLF-LSHF groups, respectively. The milk yields in the previous lactation of multiparous cows were $8880 \pm 141,8869 \pm$ 156 and $8799 \pm 180 \mathrm{~kg}$ for the control, HSLF and HSLF-LSHF groups, respectively. 
Table 1 presents the chemical composition of feeds used in the trial. Representative samples of feeds were collected weekly, then bulked monthly and analysed for chemical composition. AOAC (1990) official methods were used to determine dry matter (DM), ash, fat as ether extract, crude protein (CP) and nitrogen $(\mathrm{N} \times 6.25)$ contents of feedstuffs and pastures. Neutral detergent fibre (NDF) was determined according to Van Soest et al. (1991), using sodium sulphite anhydrous and amylase to decrease nitrogen and starch contaminations. Calcium (Ca) and phosphorus $(P)$ were determined with an inductively coupled plasma dry ashing method (ALASA dry ashing 6.1.1, RevA/98) with an Iris Advantage thermo elemental instrument, according to Giron (1973).

Table 1 Chemical composition of feeds for dairy cows used in the study

\begin{tabular}{|c|c|c|c|c|c|c|c|}
\hline \multirow[b]{2}{*}{ Parameters } & \multicolumn{4}{|c|}{ Concentrates } & \multirow[b]{2}{*}{ Pasture $^{1}$} & \multirow[b]{2}{*}{ pTMR $^{1}$} & \multirow[b]{2}{*}{ Oat hay } \\
\hline & Control & HSLF $^{1}$ & LSHF $^{1}$ & Dry period & & & \\
\hline Dry matter (g/kg as is) & 894 & 899 & 888 & 891 & 210 & 917 & 932 \\
\hline Ash (g/kg DM) & 72 & 65 & 75 & 106 & 103 & 69 & 41 \\
\hline Crude protein (g/kg DM) & 179 & 176 & 182 & 188 & 184 & 152 & 48 \\
\hline Fat as ether extract ( $g / k g ~ D M)$ & 42 & 35 & 87 & 36 & 34 & 19 & 16 \\
\hline Neutral detergent fibre (g/kg DM) & 200 & 99 & 197 & 179 & 543 & 500 & 689 \\
\hline Calcium (g/kg DM) & 14 & 12 & 13 & 29 & 5 & 5 & 3 \\
\hline Phosphorus (g/kg DM) & 7 & 9 & 10 & 7 & 5 & 3 & 2 \\
\hline
\end{tabular}

${ }^{1}$ HSLF: high starch-low fat, LSHF: low starch-high fat, Pasture: irrigated kikuyu-ryegrass pastures and pTMR: partial total mixed ration.

Table 2 Determined composition of the experimental control, HSLF and LSHF diets

\begin{tabular}{|c|c|c|c|}
\hline Postpartum diets ${ }^{4}$ & Control diet & HSLF $^{3}$ diet & $\mathrm{LSHF}^{3}$ diet \\
\hline \multicolumn{4}{|l|}{ Physical composition } \\
\hline Ryegrass-kikuyu pastures (\%) & 75.0 & 54.7 & 55.3 \\
\hline Control concentrate (\%) & 25.0 & - & - \\
\hline HSLF concentrate (\%) & - & 45.3 & - \\
\hline LSHF concentrate (\%) & - & - & 44.7 \\
\hline \multicolumn{4}{|l|}{ Chemical composition } \\
\hline Dry matter ${ }^{1}(\%)$ & 38.1 & 52.2 & 51.3 \\
\hline Metabolizabe energy ${ }^{2}(\mathrm{MJ} / \mathrm{kg})$ & 10.3 & 11.3 & 11.3 \\
\hline Neutral detergent fibre ${ }^{i}$ (g/kg DM) & 457 & 341 & 388 \\
\hline $\operatorname{Starch}^{2}(g / k g ~ D M)$ & 104 & 242 & 137 \\
\hline Fat as ether extract ${ }^{1}$ (g/kg DM) & 40 & 35 & 58 \\
\hline Crude protein $^{1}$ (CP) (g/kg DM) & 183 & 180 & 183 \\
\hline Rumen degradable protein ${ }^{2}(\% \mathrm{CP})$ & 62 & 63 & 63 \\
\hline $\mathrm{Ash}^{1}(\mathrm{~g} / \mathrm{kg} \mathrm{DM})$ & 96 & 86 & 91 \\
\hline Calcium $^{1}$ (g/kg DM) & 7.1 & 8.1 & 8.4 \\
\hline Phosphorus $^{1}$ (g/kg DM) & 5.1 & 6.3 & 6.8 \\
\hline
\end{tabular}

${ }^{1}$ Determined from chemical composition of feeds (Table 1)

${ }^{2}$ Calculated from feed formulation package (CPM-Dairy, 2006)

${ }^{3}$ HSLF: high starch-low fat, LSHF: Low starch-high fat

${ }^{4}$ Diets were estimated on DM basis using an intake of 22 and $25 \mathrm{~kg} / \mathrm{day}$ for primiparous and multiparous cows, respectively

During the postpartum period of the trial, cows were offered unrestricted access to cultivated kikuyuryegrass pastures and were supplemented with pelleted concentrates (Table 2). Pastures were irrigated, as required, using a permanent irrigation system. Cows followed a rotation programme to ensure an ad libitum DMI under normal conditions. A partial total mixed ration consisting of oat hay (48\%), lucerne hay (43\%) and soybean oil cake meal (9\%) was provided ad libitum as additional roughage when pasture availability was low. Owing to the experimental design, it was not practical to determine individual or group feed intake between treatments, because animals were allowed to graze as one herd on pastures for the experiment. Cows were milked twice daily at 05:30 and 15:00. Individually cows received half of the daily concentrate after each milk session in the milking parlour. Concentrates in treatments differed in energy levels (low 
versus high) and sources (starch versus fat). The control supplement was a maize-based concentrate containing low levels of starch, and was fed at $7 \mathrm{~kg} / \mathrm{cow} /$ day from calving until 154 DIM for both primiparous and multiparous groups. The supplement in HSLF was offered from calving to 154 DIM, and was a glucogenic concentrate, using maize as the energy source. The supplements in HSLF-LSHF were combinations of a glucogenic concentrate, offered for the first 60 DIM, similarly to HSLF, and followed from 61 to 154 DIM by a lipogenic concentrate with low starch-high fat levels containing wheat bran and Ca salts of long-chain fatty acids (Megalac rumen bypass fat, Volac International Ltd., UK) as the energy sources. The concentrate allowances in HSLF and HSLF-LSHF were $11.6 \mathrm{~kg} /$ day for primiparous and $12.6 \mathrm{~kg} / \mathrm{day}$ for multiparous dairy cows. Postpartum diets were formulated on a DM basis using an intake level of 22 and 25 $\mathrm{kg}$ DM/day for primiparous and multiparous cows, respectively. The levels of starch, ME and rumen degradable protein were estimated with the CPM Dairy software program (2006).

Diets consisted of the various levels and types of concentrates offered between treatments, with the rest of the intake being supplied by pastures. The postpartum diets were formulated to be isonitrogenous. The control diet contained a low energy level of $10.3 \mathrm{MJ} \mathrm{ME} / \mathrm{kg} \mathrm{DM}$ and had $457 \mathrm{~g} / \mathrm{kg}$ of total NDF on a DM basis. HSLF and LSHF each contained high levels of energy of $11.3 \mathrm{MJ} \mathrm{ME} / \mathrm{kg}$ DM and were formulated to improve metabolic and hormonal responses that benefited the restoration of postpartum LW. The HSLF diet consisted of $242 \mathrm{~g} / \mathrm{kg}$ of total starch content on a DM basis and was fed to increase plasma insulin and glucose levels to improve EB status. In the HSLF-LSHF combination treatment, the high starch-based diet was fed during the first 60 DIM to achieve the same objective as the HSLF treatment. Lastly, the LSHF diet was fed from 61 DIM to improve EB status using a rumen bypass fat at an inclusion level of $58 \mathrm{~g} / \mathrm{kg}$ on a DM basis, while decreasing plasma insulin level and improving plasma cholesterol level.

During the prepartum period, pregnant heifers and dry cows were weighed once a week until parturition. Calving seasons consisted of summer, from 15 October to 14 April, with December to February being the hottest months, and winter, from 15 April to 14 October, with June to August being the coldest months. Postpartum LW of dairy cows ( $n=222 ; 69$ primiparous and 153 multiparous) was recorded daily automatically after milking sessions with a calibrated electronic scale. Daily LW data were re-calculated to weekly means. The nadir point was defined as the DIM in which the lowest postpartum LW value was recorded (Sakaguchi, 2009).

The weekly LW loss was estimated as follows:

$\mathrm{LW}$ loss $_{n}=\left(\mathrm{LW}_{\text {week1 }}-\mathrm{LW}_{n}\right) \times 100(\%) / \mathrm{LW}_{\text {week1 }}$

Where $\mathrm{LW} \mathrm{loss}_{n}$ and $\mathrm{LW}_{n}$ were respectively LW loss and LW at $n$ weeks after parturition

$L W_{\text {week1 }}$ was LW within one week after parturition.

The rate of LW loss from calving to $L W_{\text {nadir }}$ was estimated in $\mathrm{kg} /$ day as follows:

Rate of $L W$ loss from calving to $L W_{\text {nadir }}=\left(L W_{\text {at calving }}-L W_{\text {nadir }}\right) /$ number of days to reach $L W_{\text {nadir }}$.

The rate of LW gain from LW nadir $_{\text {to }} 154$ DIM was estimated in kg/day as rate of LW gain from LW nadir 154 $\mathrm{DIM}=\left(\mathrm{LW}_{\text {at } 154 \text { DIM }}-\mathrm{LW}_{\text {nadir }}\right) /\left(154\right.$ - number of days to reach $\left.L W_{\text {nadir }}\right)$.

Records on prepartum and postpartum LW changes of 222 primiparous and multiparous Holstein cows were available for analyses. Among these cows, 84 were blocked, based on calving date and parity, and monitored for plasma metabolites. Blood was sampled in the summer season from October 2013 to June 2014. Blood samples were collected from the central middle coccygeal vein on the tail (Sears et al., 1978) after the morning milking session (05:30) every week from four weeks before calving to four weeks postpartum, then every three weeks to 13 weeks after calving. After blood collection, samples were centrifuged and cooled, after which the serum samples were transported with a cooler box and ice packs to a veterinary laboratory for analyses. Serum samples were analysed for plasma NEFA, BHB and urea using infrared spectrography (Thermo Scientific INDIKO analyser, Finland, 2011) and commercial kits (NEFA: FA 115 kit, Randox Laboratories Ltd, Crumlin, UK; BHB: Ranbut kit, Randox Laboratories Ltd, Crumlin, UK; and plasma urea: Urea Thermo Scientific INDIKO procedure reference 981818/981820). Plasma concentrations of BHB were analysed only during the postpartum period. The accuracy of each assay was monitored with a commercial reference serum sample (Bovine precision serum, Randox Ltd) and all coefficients of variation between analyses were $<5 \%$.

Data were analysed using the PROC MIXED of SAS enterprise guide (SAS, 2012), grouped according to parity groups, that is, primiparous and multiparous cows. To avoid problems of fitting a covariance structure in the statistical model, prepartum and postpartum data were analysed separately. The statistical model included year $(Y)$ effect, calving season $(S)$ effect, treatment $(T)$ effect, week (W) effect of observations and the interaction effects between treatment and week of observation (WT) as well as treatment and calving season (ST) as fixed effects, while the animal effect within treatments was specified as a random effect. The effects of year and season of calving were included in the statistical model because of the duration of the experiment. The variables obtained every day within a particular week during the trial were regarded as repeated observations of that particular week block. The approach was to account for the 
daily data variations within each week of observations to reduce the error variance of treatment effects in the statistical analysis. Second, this repeated observation permitted a longitudinal analysis to monitor the ways in which the weekly means changed over time. The statistical model was as follows:

Model $=\mu+Y_{i}+S_{j}+T_{k}+W_{l}+(S T)_{j k}+(W T)_{k l}+\delta_{(l k) m}+\varepsilon_{i j k l m}$, where

$\mu=$ overall mean

$Y_{i}=$ the fixed effect of the $i^{\text {th }}$ year of calving (i.e. 2012, 2013 and 2014)

$S_{j}=$ the fixed effect of the $j^{\text {th }}$ season of calving (i.e. summer and winter)

$T_{k}=$ the fixed effect of the $k^{\text {th }}$ treatment (i.e. Control, HSLF and HSLF-LSHF)

$W_{l}=$ the fixed effect of the $t^{\text {th }}$ week of observation (i.e. 1 to 22)

$(S T)_{j k}=$ the interaction between levels of the $j^{\text {th }}$ season of calving and $k^{\text {th }}$ treatment

$(W T)_{k l}=$ the interaction between levels of the $l^{\text {th }}$ week of sampling and $k^{\text {th }}$ treatment

$\delta_{(k l) m}=$ the variable effect of the $m^{\text {th }}$ block effect in the $k^{\text {th }}$ treatment (repeated statement)

$\varepsilon_{i j k l m}=$ the random experimental error

Prepartum LW were analysed without the repeated statement $\left(\delta_{(k l) m}\right)$, while all effects were used to analyse postpartum LW in the statistical model. Because blood was collected every week in one summer season, plasma metabolites were analysed without the repeated statement $\left(\delta_{(k) m)}\right)$, as well as year and calving season effects in the statistical model. LW traits generated from the postpartum LW curves were analysed without the repeated statement $\left(\delta_{(k l) m}\right)$, using year, calving season, treatment and the interaction between treatment and calving season as fixed effects in the statistical model. Statistical assumptions were described as fixed effects and their interactions were equal to zero with $\delta_{(k l) m} \sim \mathrm{N}\left(0, \sigma_{\mathrm{e}}{ }^{2}\right) \mathrm{varying}$ independently of $\varepsilon_{i j k l m}$. Differences in means and standard error (SE) of means between treatments were obtained using the pairwise comparison of the Bonferroni t-test. Significance was declared at $P<0.05$. Interactions were reported as NS (not significant) if $P>0.05$.

\section{Results and Discussion}

The effects of nutritional treatments on the plasma NEFA and BHB for primiparous and multiparous cows are presented in Table 3.

Table 3 Least square means ( \pm SE) of non-esterified fatty acid and $\beta$-hydroxybutyrate recorded for primiparous and multiparous cows for a four week prepartum to 13 week postpartum period

\begin{tabular}{|c|c|c|c|c|c|c|}
\hline \multirow[b]{2}{*}{ Parameters } & \multicolumn{3}{|c|}{ Concentrate feeding } & \multicolumn{3}{|c|}{$P$-values } \\
\hline & Control & HSLF $^{1}$ & HSLF-LSHF1 & $T^{2}$ & $W^{2}$ & $W T^{2}$ \\
\hline \multicolumn{7}{|l|}{ Primiparous cows } \\
\hline Number of cows & 13 & 6 & 6 & & & \\
\hline \multicolumn{7}{|c|}{ Non-esterified fatty acid (mmol/L) } \\
\hline Prepartum & $0.29 \pm 0.05$ & $0.32 \pm 0.06$ & $0.31 \pm 0.03$ & 0.34 & 0.82 & NS \\
\hline Postpartum & $0.56^{\mathrm{a}} \pm 0.08$ & $0.37^{b} \pm 0.06$ & $0.37^{b} \pm 0.08$ & 0.02 & 0.12 & NS \\
\hline \multicolumn{7}{|c|}{$\beta$-Hydroxybutyrate (mmol/L) } \\
\hline Postpartum & $0.57^{a} \pm 0.04$ & $0.35^{b} \pm 0.04$ & $0.43^{b} \pm 0.03$ & 0.001 & 0.92 & NS \\
\hline \multicolumn{7}{|l|}{ Multiparous cows } \\
\hline Number of cows & 25 & 19 & 19 & & & \\
\hline Lactation number & $3.82 \pm 0.17$ & $3.49 \pm 0.22$ & $3.54 \pm 0.22$ & & & \\
\hline \multicolumn{7}{|c|}{ Non-esterified fatty acid (mmol/L) } \\
\hline Prepartum & $0.25 \pm 0.02$ & $0.24 \pm 0.02$ & $0.28 \pm 0.03$ & 0.19 & 0.002 & NS \\
\hline Postpartum & $0.29 \pm 0.02$ & $0.28 \pm 0.03$ & $0.30 \pm 0.03$ & 0.50 & $<.001$ & NS \\
\hline \multicolumn{7}{|c|}{$\beta$-Hydroxybutyrate (mmol/L) } \\
\hline Postpartum & $0.51 \pm 0.02$ & $0.47 \pm 0.02$ & $0.49 \pm 0.02$ & 0.40 & 0.31 & NS \\
\hline
\end{tabular}

${ }^{1}$ HSLF: high starch-low fat, HSLF-LSHF: high starch-low fat/low starch-high fat.

${ }^{2} T$ : treatment, $W$ : week of observation, $W T$ : interaction between week of observation and treatment.

$\mathrm{a}, \mathrm{b}, \mathrm{c}$ Row means with different superscripts differ significantly at $P<0.05$.

Plasma NEFA did not differ $(P>0.05)$ during the prepartum period in the primiparous and the multiparous groups, as expected, because cows were maintained under the same prepartum feeding and management conditions. Postpartum plasma NEFA and BHB were similar between treatments for multiparous cows. Also, an interaction between treatment and week of observation was not recorded for multiparous cows. In the primiparous cows, postpartum plasma NEFA and BHB increased $(P<0.05)$ in animals offered the control concentrate, compared with those that received the HSLF and HSLF-LSHF 
concentrates. However, the interaction between diet and time of observation was not affected. In both parity groups, the changes in NEFA and BHB over time were as expected during transition (Figures 1 and 2). These variations in both parity groups indicated the overstressed ability of cows to adapt to the energy shortfall caused by the energy requirement exceeding the nutrient intake around parturition. Supporting the current results of energy metabolites, other studies found that plasma NEFA and BHB levels were significantly elevated in cows during early lactation (Adewiyi et al., 2005; Van Knegsel et al., 2007a; McArt et al., 2013; Schulz et al., 2014).

The variations in plasma NEFA and BHB over time are illustrated in Figure 2 for primiparous cows and Figure 3 for multiparous cows, respectively.

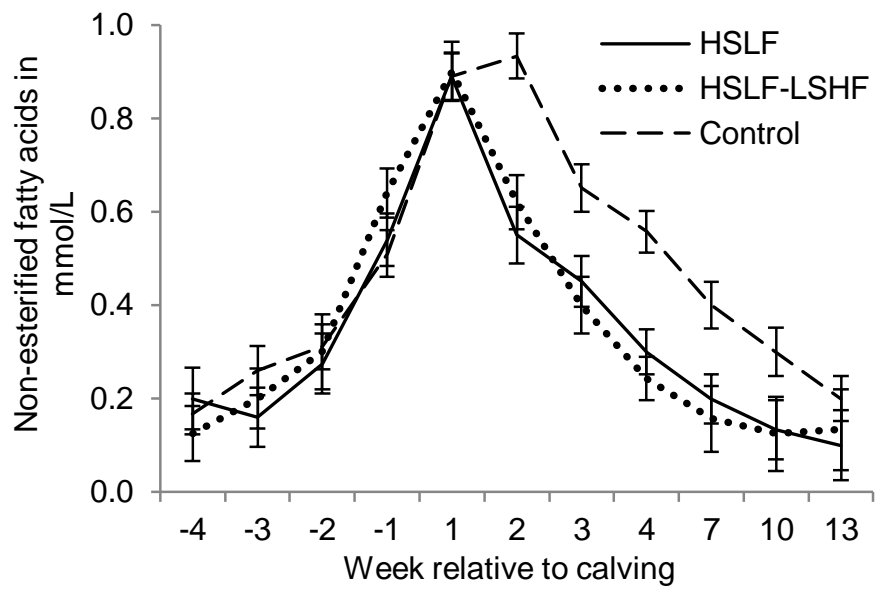

(a)

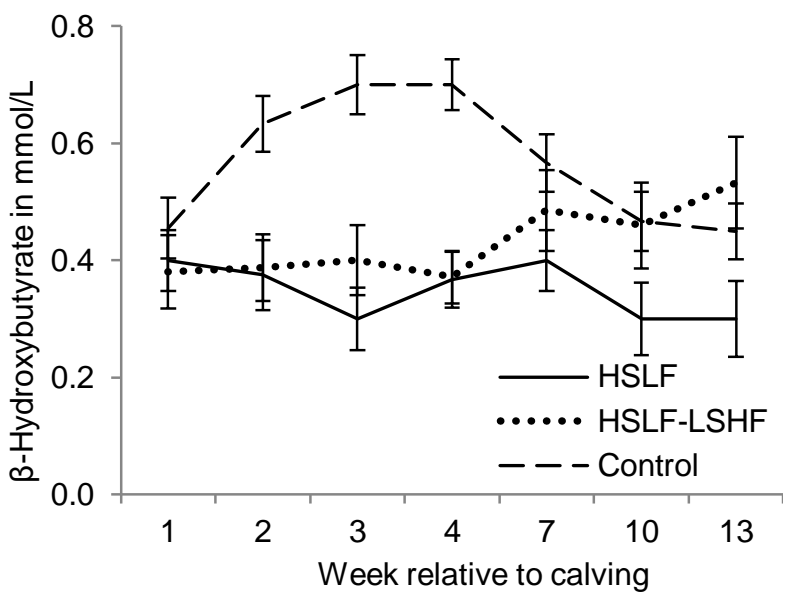

(b)

Figure 1 Least square means ( \pm SE) of non-esterified fatty acids (a) and $\beta$-hydroxybutyrates (b) recorded for primiparous cows for a 4-week prepartum to 13-week postpartum period [HSLF: high starch-low fat, HSLFLSHF: high starch-low fat/low starch-high fat]

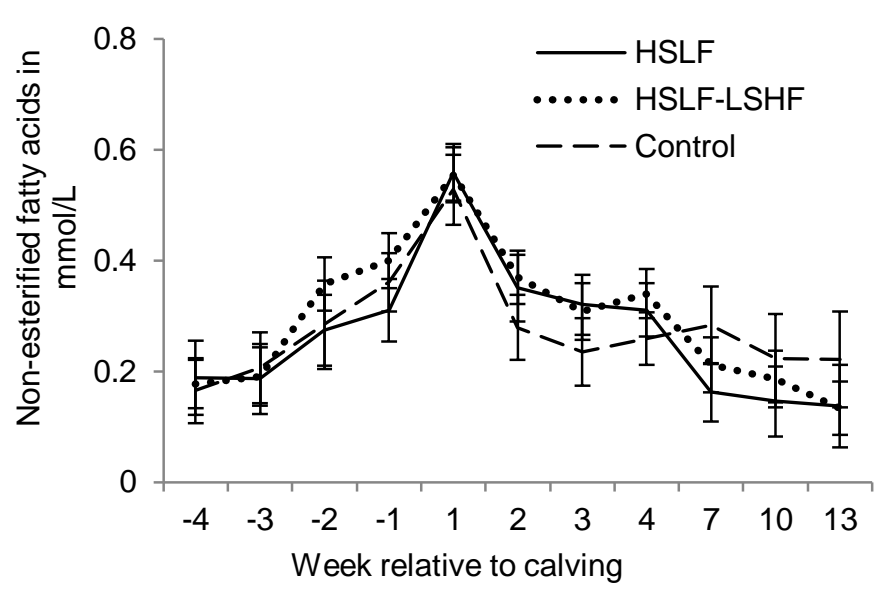

(a)

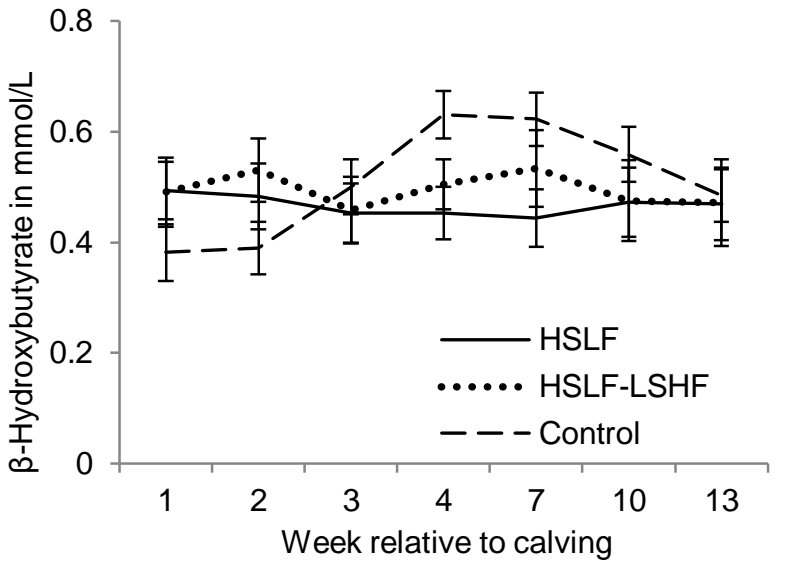

(b)

Figure 2 Least square means ( \pm SE) of non-esterified fatty acids (a) and $\beta$-hydroxybutyrates (b) recorded for multiparous cows during a four week prepartum to 13 week postpartum period [HSLF: high starch-low fat, HSLF-LSHF: high starch-low fat/low starch-high fat]

An NEB generally occurs before and after calving since the demands for glucose, fatty acids and amino acids for foetal growth or milk production outweigh the increase in voluntary DMI in dairy cows (Hammon et al., 2009), owing to limitations in intake and appetite (Overton \& Waldron, 2004; Walsh et al., 2011). In addition, plasma somatotropin increases after calving, resulting in the partitioning of absorbed nutrients from digestion in the liver and from adipose tissues towards milk production (Chagas et al., 2007). In the liver, the increase in growth hormone $(\mathrm{GH})$ directly stimulates gluconeogenesis and indirectly antagonizes the production of insulin, essentially to meet glucose demands for milk production (Lucy, 2004). 
In adipose tissue, GH increases lipolysis. This breakdown supplies fatty acids to the mammary gland for the synthesis of the milk triglycerides (Drackley, 2000; Van Knegsel et al., 2007a) and alternative energy sources in the form of NEFA and BHB used as additional fuels to meet the energy requirements (Goff \& Horst, 1997; Van Knegsel et al., 2007a, b). A certain level of NEFA and BHB in the bloodstream is regarded in periparturient cows as a normal adaptation to the NEB (McArt et al., 2013). Levels of plasma NEFA and BHB increase slowly at the end of the DP, as cows approach calving time, and peak at calving (Adewiyi et al., 2005). Levels remain high after calving, indicating a status of NEB and ketosis (Schulz et al., 2014). The levels of plasma NEFA and BHB decline to lower levels by six weeks after calving (Adewiyi et al., 2005). This reaction occurs as a biological mechanism to periparturient stresses and changes in physiological, metabolic and endocrinal status, indispensable for the cow maintenance and body growth, pregnancy needs (i.e. foetus and its membranes, uterus, mammary gland), parturition and lactogenesis (Contreras \& Sordillo, 2011; McArt et al., 2013; Wankhade et al., 2017).

Importantly, feeding glucogenic-based diets during early lactation resulted in decreased plasma NEFA and BHB concentrations (Lemosquet et al., 1997; Pickett et al., 2003; Reist et al., 2003), while lipogenicbased diets led to increased plasma NEFA and BHB levels (Moallen et al., 1997; Drackley et al., 2003; Ponter et al., 2006). However, other studies showed no effects of energy-based diets on energy biomarkers, probably because of the similar energy levels between diets (Van Knegsel et al., 2007a; Roche et al., 2013). Van Knegsel et al. (2007b) found that plasma NEFA and BHB of primiparous cows were similar, but differed in multiparous cows, with levels being significantly higher in cows fed mixed and lipogenic diets, compared with a glucogenic diet. Recently, the association of various cut-points of elevated NEFA and BHB levels with adverse postpartum health and production problems has been investigated in identifying animals with poor adaptation to NEB. Prepartum NEFA cut-points measured 14 to 3 days prior to calving ranged from 0.3 to $0.5 \mathrm{mmol} / \mathrm{L}$, whereas postpartum cut-points measured from 1 to $14 \mathrm{DIM}$ were from 0.70 to $1.0 \mathrm{mmol} / \mathrm{L}$ for NEFA and 0.9 to $1.4 \mathrm{mmol} / \mathrm{L}$ for BHB, respectively (Ospina et al., 2010a, b; Chapinal et al., 2011). Above these cut-points, postpartum disruptions could include increased incidences of peripartum diseases, lower milk yields, early culling from the herd and poor fertility (Van Knegsel et al., 2007a; Giuliodori et al., 2011; Seifi et al., 2011; Evans \& Walsh, 2012; McArt et al., 2013; Esposito et al., 2014; ; Wankhade et al., 2017). In this study, changes in plasma NEFA over time indicated that all cows relied $(P<0.05)$ on the mobilization of body reserves to satisfy the nutrient demand during transition (i.e. NEFA $>0.5 \mathrm{mmol} / \mathrm{L}$ in one week before calving and peaking after calving. (See Figure 1(a) for primiparous and Figure 2(a) for multiparous cows, respectively.) Also, the increase in postpartum plasma NEFA and BHB levels $(P<0.05)$ in grazing primiparous cows that received $7 \mathrm{~kg} / \mathrm{cow} /$ day of concentrate in the control group indicated higher lipolysis and possible subclinical ketosis compared with those that received $11.6 \mathrm{~kg} / \mathrm{cow} /$ day of concentrates in the HSLF and HSLF-LSHF treatment groups (Figure 1). A possible explanation for the alterations in energy biomarkers could be the high starch and fat levels being fed to cows. Although it was not measured in this study, feeding more starch in the first 60 days post partum in HSLF and HSLF-LSHF treatments presumably increased glucose and insulin levels (Garnsworthy et al., 2008a; Lammoglia et al., 1997), subsequently facilitated the uptake of NEFA (Lee \& Hossner, 2002; Van Knegsel et al., 2007a; Garnsworthy et al., 2008a, 2009) and decreased lipolysis of body fat reserves (Lafontan et al., 2009), compared with the control. Another explanation could be related to the differences in parity of dairy cows. Normally, dairy heifers calve for the first time at approximately 24 months old, making them not physically mature at this stage (Coffey et al., 2006). Primiparous cows during transition are thus in a different metabolic status from multiparous cows as they need nutrients for their own growth in addition to that of the developing calf before calving or for milk synthesis after calving (Wathes et al., 2007; McArt et al., 2013). The observed variations in NEFA and BHB levels in this study suggest possible divergences in the control of mobilization of body reserves between primiparous and multiparous cows, which encourage nutrient partitioning into animal growth and milk production during the first lactation. The lack of effects of nutritional treatments on postpartum NEFA and BHB levels could be attributed to the possible advanced hepatic adaptation in matured multiparous cows (parity > 3) to postpartum energy stress, compared with young still growing primiparous cows.

The effects of nutritional treatments on blood urea for primiparous and multiparous cows are presented in Table 4. Changes in plasma urea over time are illustrated in Figure 3(a) for primiparous cows and Figure 3(b) for multiparous cows, respectively. As expected, prepartum plasma urea levels did not differ significantly between treatments in the primiparous and multiparous groups, as prepartum diets and management conditions were similar. Postpartum treatments did not affect plasma urea levels of primiparous cows. The interaction between treatment and time of observation was significant $(P<0.05)$, with the control being lower compared with the groups that received HSLF and HSLF-LSHF concentrates (Figure 3(a)). In multiparous cows, HSLF and HSLF-LSHF treatments increased $(P<0.05)$ plasma urea levels, compared with the control (Figure 3(b)). However, the interaction between treatment and time of observation on plasma urea levels was not significant in multiparous cows. 
Table 4 Least square means ( \pm SE) of plasma urea recorded for primiparous and multiparous cows for a 4week prepartum to 13-week postpartum period

\begin{tabular}{lcccccc}
\hline & \multicolumn{3}{c}{ Concentrate feeding } & \multicolumn{3}{c}{$\boldsymbol{P}$-values } \\
\cline { 2 - 7 } Parameters & Control & HSLF $^{1}$ & HSLF-LSHF $^{1}$ & $\boldsymbol{T}^{2}$ & $\boldsymbol{W}^{2}$ & $\boldsymbol{W T}^{2}$ \\
\hline Primiparous cows & & & & & & \\
Number of cows & 13 & 6 & 6 & & & \\
Prepartum blood urea (mmol/L) & $3.37 \pm 0.51$ & $3.34 \pm 0.71$ & $3.48 \pm 0.84$ & 0.74 & 0.2 & $\mathrm{NS}$ \\
Postpartum blood urea (mmol/L) & $5.17^{\mathrm{a}} \pm 0.32$ & $5.78^{\mathrm{b}} \pm 0.38$ & $5.57^{\mathrm{b}} \pm 0.28$ & 0.62 & 0.01 & 0.04 \\
$\quad$ Multiparous cows & & & & & & \\
Number of cows & 25 & 19 & 19 & & & \\
Prepartum blood urea (mmol/L) & $3.54 \pm 0.23$ & $3.50 \pm 0.30$ & $3.42 \pm 0.30$ & 0.08 & 0.47 & $\mathrm{NS}$ \\
Postpartum blood urea (mmol/L) & $5.27^{\mathrm{a}} \pm 0.18$ & $6.05^{\mathrm{b}} \pm 0.22$ & $6.71^{\mathrm{b}} \pm 0.25$ & $<.001$ & 0.27 & $\mathrm{NS}$ \\
\hline
\end{tabular}

${ }^{1}$ HSLF: high starch-low fat, HSLF-LSHF: high starch-low fat/low starch-high fat

${ }^{2} T$ : treatment, $W$ : week of observation, $W T$ : interaction between week of observation and treatment

${ }^{a}, b, c$ Row means with different superscripts differ significantly at $P<0.05$

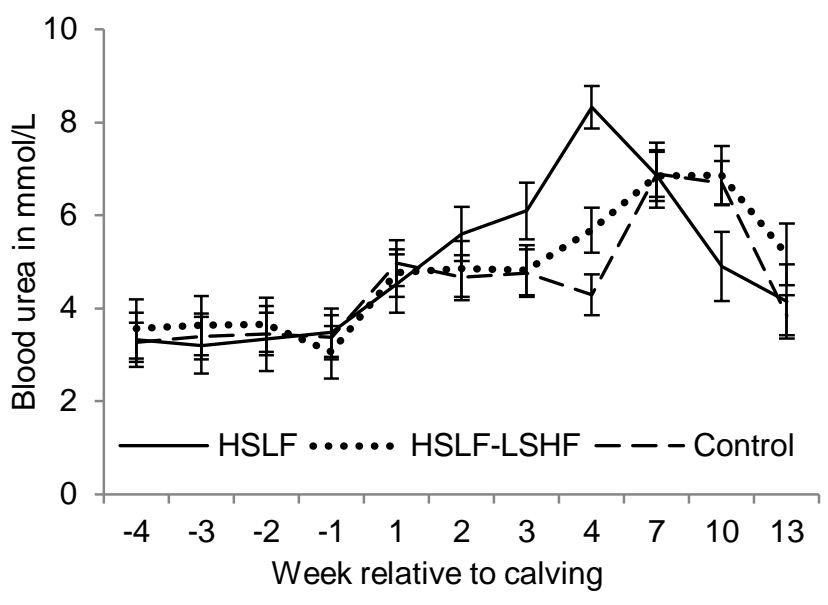

(a)

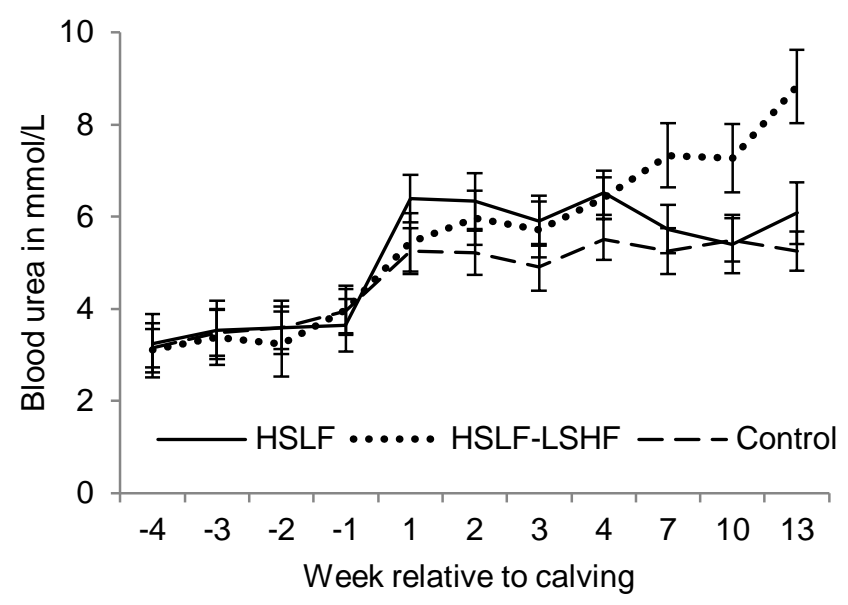

(b)

Figure 3 Least square means ( \pm SE) of plasma urea concentrations recorded for primiparous (a) and multiparous (b) cows for a 4-week prepartum to 13-week postpartum period [HSLF: high starch-low fat, HSLF-LSHF: high starch-low fat/low starch-high fat]

Various factors contribute to plasma urea levels that are measured close to parturition and in early lactating ruminants. During transition, energy and protein in the diet of cows are limiting as a result of the requirements for foetal growth or milk production (Wathes et al., 2007). As a result, low glucose availability is supplemented by an increased rate of gluconeogenesis, which relies on amino acids mobilized from body muscles at the cost of protein synthesis, thus increasing plasma urea production (Bell, 1995; Garnsworthy et al., 2008b). Furthermore, plasma urea levels were reported to increase in situations in which dietary protein supply exceeds energy availability (Oltner \& Wiktorsson, 1983; Moore \& Varga, 1996). When the energy supply is restricted, the amount of ammonia production from dietary crude protein exceeds the capability of the rumen microbes to convert it into microbial protein synthesis (MPS) (Wathes et al., 2007). This situation increases the circulating plasma ammonia levels, with the excess being converted to urea by the liver (Carlsson \& Pehrson, 1994). In previous studies, plasma urea concentrations decreased for cows fed a glucogenic diet, compared with those that were fed a lipogenic diet (Van Knegsel et al., 2007a; Garnsworthy et al., 2008a, 2009). However, Van Knegsel et al. (2007b) found no differences in blood urea levels in primiparous and multiparous cows fed glucogenic, mixed or lipogenic diets. In contrast, plasma urea levels in this study showed a positive relationship with the inclusion level (high versus low) of concentrates, indicating poor $\mathrm{N}$ utilization in the rumen in HSLF and HSLF-LSHF compared with the control in both parity groups (Figure 3). Normally, high starch diets improve rumen ammonia capture and decrease plasma urea levels (Reynolds, 2006). The inverse effect in this study could be attributed the structural properties of the pelleted concentrates impeding the rumen fermentation, when grazing cows were fed high levels of concentrates (i.e. $11.6 \mathrm{~kg} /$ day for primiparous and $12.6 \mathrm{~kg} /$ day for multiparous cows, respectively) compared with a low level (i.e. $7 \mathrm{~kg} /$ day for primiparous and multiparous cows). The heat treatment in the pelleting 
process probably increased its resistance to rumen fermentation and rapidly bypassed the energy nutrients to the small intestine, thus preventing $\mathrm{N}$ capture for MPS in the rumen.

The effects of feeding treatments on LW traits are presented in Table 5 for primiparous and multiparous cows, respectively. The effects of year of calving and season of calving on prepartum and postpartum LW and on postpartum LW loss were not significant for both primiparous and multiparous groups (therefore, $P$-values of the effect of year of calving were not indicated in Table 5). Changes in LW and LW loss over week of observation are illustrated in Figure 4 for primiparous cows and Figure 5 for multiparous cows, respectively. Prepartum LW was similar for primiparous (Figure 4) and multiparous cows (Figure 5), owing to the similar feeding and management conditions during this period. Pregnant heifers and dry cows gained LW as calving time approached (Figures 4(a) and 5(b)) (week of observation $P<0.05$ not reported in Table 5), as would be expected with increased foetal growth during late pregnancy. Approximately $60 \%$ in foetal mass, relative to the calf LW at birth, occurs in the last two months of the pregnancy (Bauman \& Currie, 1980). Through the homeorhetic pathway that controls the pregnancy, glucose and amino acids are partitioned for the development of the foetus, and for the growth of the foetal membranes, gravid uterus, and the mammary gland. In addition, the foetus of a ruminant is more vulnerable to maternal undernutrition stresses than that of many other species, resulting in severe foetal growth delay (Everitt, 1964). Hence, maternal adaptions in prepartum heifers and cows prioritized the nutrients required for their own maternal growth and for replenishment of protein and energy reserves to meet the foetal requirements. In this study, the lack of differences in prepartum LW of heifers and dry cows could be related to the partitioning of nutrients during pregnancy to support the foetal needs in both parity groups.

Table 5 Least square means $( \pm$ SE) of live weight traits recorded for primiparous and multiparous cows during an eight week prepartum to 22 week postpartum period

\begin{tabular}{|c|c|c|c|c|c|c|}
\hline \multirow[b]{2}{*}{ Parameters } & \multicolumn{3}{|c|}{ Concentrate feeding } & \multicolumn{3}{|c|}{$P$-values } \\
\hline & Control & HSLF $^{1}$ & $\begin{array}{l}\text { HSLF- } \\
\text { LSHF }^{1}\end{array}$ & $T^{2}$ & $S^{2}$ & $S T^{2}$ \\
\hline \multicolumn{7}{|l|}{ Primiparous cows } \\
\hline Number of cows & 30 & 20 & 19 & - & - & - \\
\hline $\mathrm{LW}^{3}$ from week 8 to 1 prepartum $(\mathrm{kg})$ & $522 \pm 9$ & $524 \pm 11$ & $520 \pm 11$ & 0.21 & 0.81 & NS \\
\hline LW $^{3}$ week 1 after calving (kg) & $511 \pm 14$ & $493 \pm 13$ & $491 \pm 9$ & 0.43 & 0.53 & NS \\
\hline $\mathrm{LW}_{\text {nadir }}^{3}(\mathrm{~kg})$ & $429 \pm 10$ & $435 \pm 9$ & $438 \pm 7$ & 0.76 & 0.77 & NS \\
\hline $\mathrm{LW}^{3}$ loss nadir $(\mathrm{kg})$ & $79^{a} \pm 8$ & $58^{b} \pm 7$ & $54^{b} \pm 5$ & 0.04 & 0.99 & NS \\
\hline Number of days to reach $\mathrm{LW}^{3}{ }_{\text {nadir }}$ (days) & $40^{a} \pm 3$ & $26^{b} \pm 2$ & $25^{b} \pm 3$ & 0.01 & 0.94 & NS \\
\hline Rate of $\mathrm{LW}^{3}$ loss from calving to $\mathrm{LW}^{3}$ nadir (kg/day) & $2.09 \pm 0.29$ & $2.43 \pm 0.36$ & $2.87 \pm 0.37$ & 0.15 & 0.84 & NS \\
\hline LW at peak milk yield (kg) & $468 \pm 10$ & $465 \pm 13$ & $463 \pm 11$ & 0.94 & 0.83 & NS \\
\hline Rate of $\mathrm{LW}^{3}$ gain from $\mathrm{LW}_{\text {nadir }}$ & $0.57 \pm 0.04$ & $0.69 \pm 0.05$ & $0.60 \pm 0.05$ & 0.16 & 0.35 & NS \\
\hline $\mathrm{LW}^{3}$ from week 1 to 22 postpartum $(\mathrm{kg})$ & $479^{a} \pm 9$ & $488^{\mathrm{b}} \pm 11$ & $489^{b} \pm 11$ & $<.01$ & 0.98 & $<.01$ \\
\hline $\mathrm{LW}^{3}$ loss from week 2 to 22 postpartum (\%) & $6.13^{a} \pm 0.40$ & $-0.92^{b} \pm 27$ & $-0.27^{b} \pm 0.40$ & $<.01$ & 0.87 & $<.01$ \\
\hline \multicolumn{7}{|l|}{ Multiparous cows } \\
\hline Number of cows & 77 & 38 & 38 & - & - & - \\
\hline Lactatior & $3.82 \pm 0.17$ & $3.49 \pm 0.22$ & $3.54 \pm 0.22$ & - & - & - \\
\hline $\mathrm{LW}^{3}$ from week 8 to 1 prepartum $(\mathrm{kg})$ & $660 \pm 7$ & $662 \pm 7$ & $662 \pm 7$ & 0.12 & 0.41 & NS \\
\hline $\mathrm{LW}^{3}$ week 1 after calving $(\mathrm{kg})$ & $621 \pm 8$ & $630 \pm 10$ & $620 \pm 11$ & 0.11 & 0.51 & NS \\
\hline $\mathrm{LW}_{\text {nadir }}^{3}(\mathrm{~kg})$ & $541 \pm 6$ & $563 \pm 9$ & $557 \pm 10$ & 0.39 & 0.59 & NS \\
\hline LW $^{3}$ loss $_{\text {nadir }}(\mathrm{kg})$ & $75 \pm 4$ & $68 \pm 3$ & $66 \pm 3$ & 0.24 & 0.22 & NS \\
\hline Number of days to reach $\mathrm{LW}^{3}{ }_{\text {nadir }}$ (days) & $35 \pm 2$ & $28 \pm 3$ & $29 \pm 3$ & 0.07 & 0.44 & NS \\
\hline Rate of $\mathrm{LW}^{3}$ loss from calving to $\mathrm{LW}^{3}$ nadir (kg/day) & $2.56 \pm 0.15$ & $2.85 \pm 0.22$ & $2.49 \pm 0.21$ & 0.43 & 0.83 & NS \\
\hline LW at peak milk yield $(\mathrm{kg})$ & $580 \pm 7$ & $597 \pm 10$ & $595 \pm 10$ & 0.23 & 0.74 & NS \\
\hline Rate of $\mathrm{LW}^{3}$ gain from $\mathrm{LW}_{\text {nadir }}$ to $154 \mathrm{DIM}^{3}$ (kg/day) & $0.54 \pm 0.03$ & $0.49 \pm 0.04$ & $0.48 \pm 0.04$ & 0.33 & 0.37 & NS \\
\hline $\mathrm{LW}^{3}$ from week 1 to 22 postpartum $(\mathrm{kg})$ & $583^{a} \pm 7$ & $603^{b} \pm 7$ & $604^{b} \pm 7$ & $<.01$ & 0.21 & NS \\
\hline $\mathrm{LW}^{3}$ loss from week 2 to 22 postpartum (\%) & $5.85^{a} \pm 0.62$ & $4.18^{b} \pm 0.78$ & $2.73^{b} \pm 0.70$ & $<.01$ & 0.89 & $<.01$ \\
\hline
\end{tabular}

\footnotetext{
${ }^{1}$ HSLF: high starch-low fat, HSLF-LSHF: high starch-low fat/low starch-high fat

${ }^{2} T$ : treatment, $W$ : week of observation, $W T$ : interaction between season of calving and treatment

${ }^{3} \mathrm{LW}$ : live weight, DIM: days in milk

a, b, c Row means with different superscripts differ significantly at $P<0.05$
} 
In both seasons, higher $(P<0.05)$ postpartum LW in primiparous and multiparous cows was recorded for HSLF and HSLF-LSHF treatments, compared with the control groups (results not reported in Table 5). In primiparous groups, the postpartum LW for the control, HSLF and HSLF-LSHF treatments was 482 \pm 4 ; 495 \pm 4 and $497 \pm 4 \mathrm{~kg}$ in winter versus $477 \pm 3 ; 480 \pm 4$ and $481 \pm 4 \mathrm{~kg}$ in the summer season, respectively. In multiparous groups, postpartum LW for the control, HSLF and HSLF-LSHF treatments was $579 \pm 2 ; 595 \pm 3$ and $600 \pm 2 \mathrm{~kg}$ in winter versus $588 \pm 2 ; 612 \pm 3$ and $608 \pm 3 \mathrm{~kg}$ in summer, respectively.

Postpartum LW was the lowest $(P<0.05)$ and LW loss was highest $(P<0.05)$ in cows that received the control diet compared with HSLF and HSLF-LSHF diets for primiparous (Figure 4) and multiparous cows (Figure 5). The interaction between treatment and week of observation on postpartum LW and LW loss was significant $(P<0.05)$ in both primiparous and multiparous groups $(P$-values not indicated in Table 5$)$. Also, the interaction between season and treatment on postpartum LW and LW loss was significant $(P<0.05)$ in primiparous and multiparous cows. The LW loss $_{\text {nadir }}$ and the number of days to reach $\mathrm{LW}_{\text {nadir }}$ increased $(P<$ 0.05 ) in primiparous cows that received the control concentrate, compared with HSLF and HSLF-LSHF treatments. This trend was not evident in multiparous cows. A possible explanation could be poor hepatic adaptation to postpartum energy stress and increased LW mobilization in young still growing primiparous cows, compared with mature multiparous cows (parity $>3$ ).

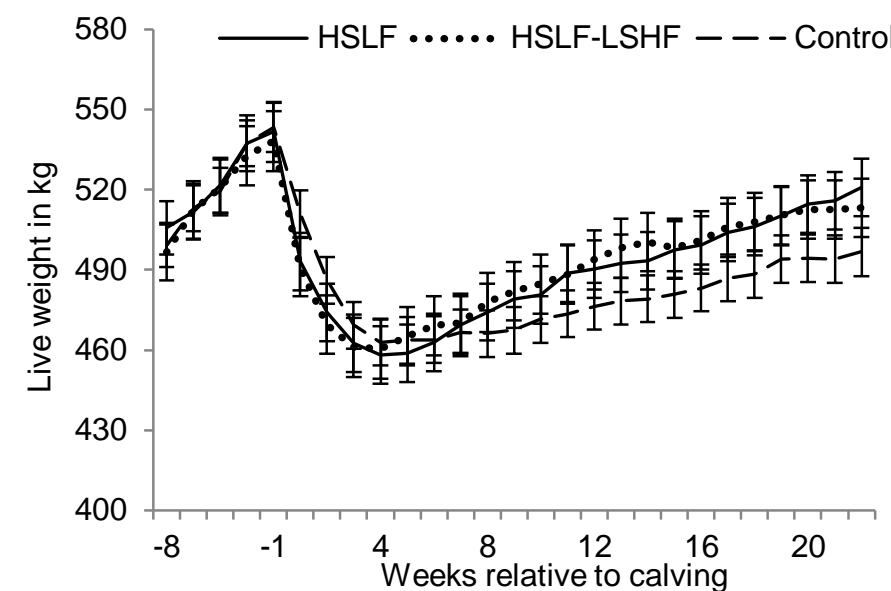

(a)

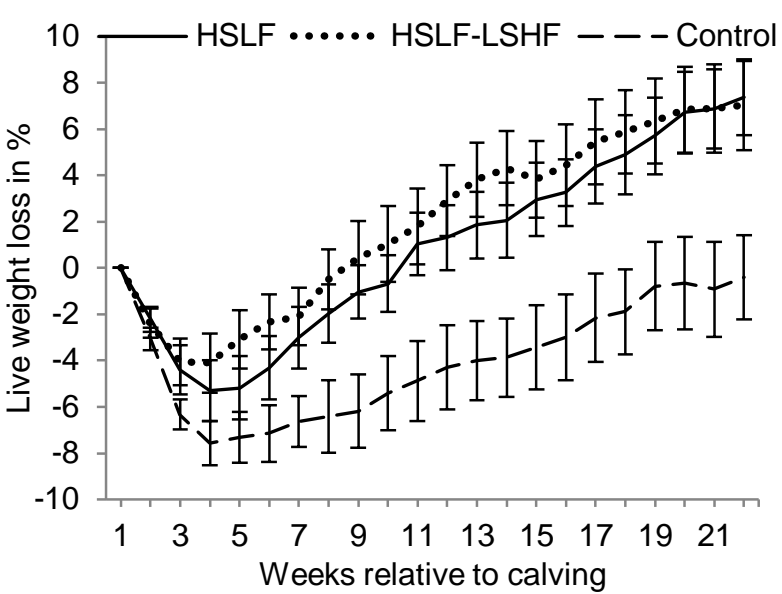

(b)

Figure 4 Least square means ( \pm SE) of postpartum live weight (a) and postpartum live weight loss (b) recorded for primiparous cows during a 22 week postpartum period [HSLF: high starch-low fat, HSLF-LSHF: high starch-low fat/low starch-high fat]

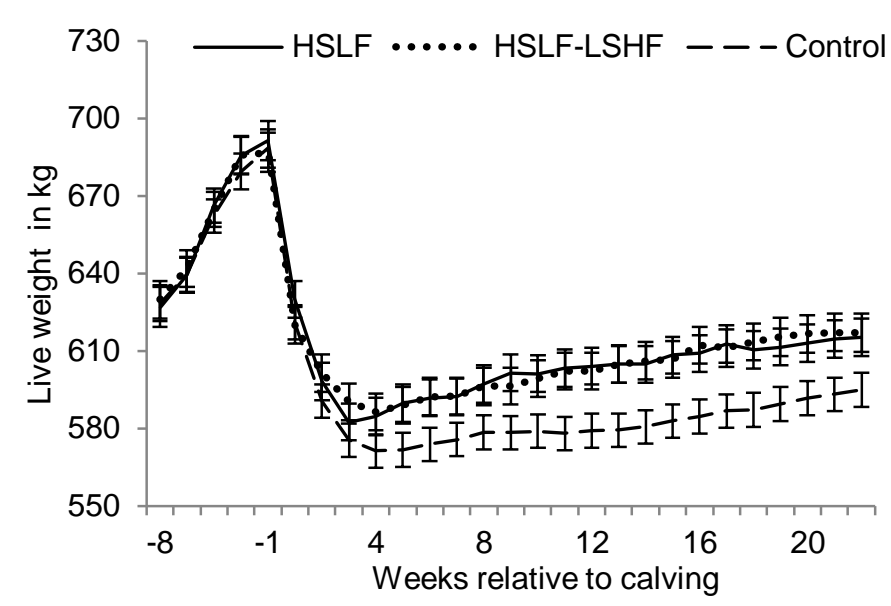

(a)

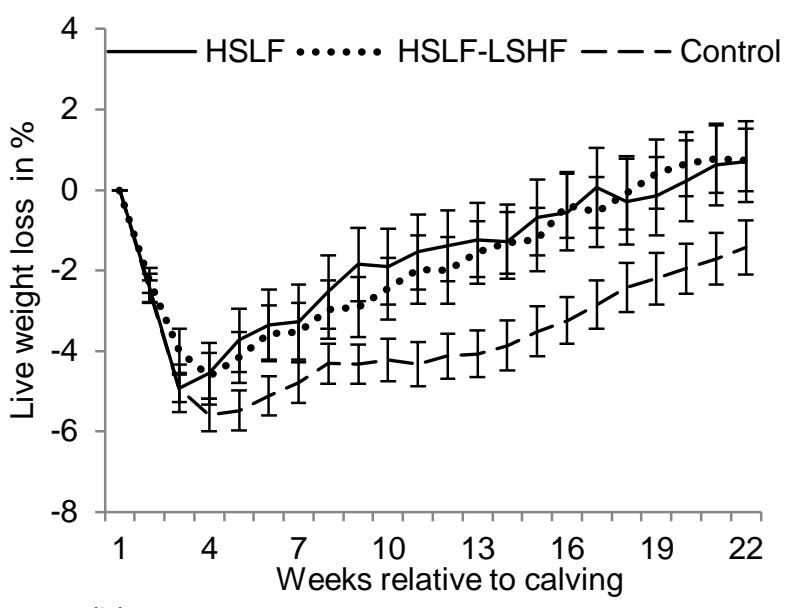

(b)

Figure 5 Least square means ( \pm SE) of postpartum live weight (a) and postpartum live weight loss (b) recorded for primiparous cows during a 22 week postpartum period [HSLF: high starch-low fat, HSLF-LSHF: high starch-low fat/low starch-high fat] 
Tamminga et al. (1997) found that the energy partitioning into milk from the mobilization of body fat and protein reserves after parturition resulted in a LW loss in cows fed $11.1 \mathrm{~kg} / \mathrm{day}$ of roughage and 10.8 $\mathrm{kg} /$ day of concentrates on a DM basis. In the eight weeks of the trial period, cows mobilized an average of $0.7 \mathrm{~kg} \mathrm{LW}$, namely $0.56 \mathrm{~kg}$ fat and $0.04 \mathrm{~kg}$ protein per day. The LW loss due to this mobilization was highest in the first week after calving and decreased as the lactation period progressed (Tamminga et al., 1997). Previous studies also reported LW losses during the postpartum period (Senatore et al., 1996; Garnsworthy, 2002; Buckley et al., 2003; Lucy, 2007; Sakaguchi, 2009). However, other studies found no effects on LW (Van Knegsel et al., 2007a; Garnsworthy et al., 2009), probably because of the iso-energetic diets used in the studies. In the current study, postpartum LW of cows in both parity groups decreased until the nadir point in early lactation and increased afterwards. During early lactation, the shift of the somatotropic axis towards improved milk synthesis was reported to be associated with increased prioritization of nutrients to satisfy the demands of the mammary gland at the expense of body reserves and LW (Leroy et al., 2008). Jorritsma et al. (2003) reported that a postpartum cow that is undergoing continuous weight loss over time is in a state of NEB, while a cow that gains weight over time is preventing a mobilization of body reserves to

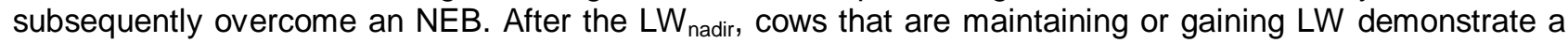
positive indicator towards process of stabilising or improving the EB status in these cows (Van Straten et al., 2008). Consistent with these arguments, postpartum LW of cows in this study decreased in the control group in comparison to HSLF and HSLF-LSHF treatments in both parity groups, indicating differences in nutritional status between treatments as the lactation progressed. This finding showed that abnormal deviations in LW over time could be utilized as a proxy to identify the physiological well-being and the nutritional status of each cow in the herd in response to managerial purposes (e.g. nutritional treatment according to performance or to prevent undesired LW loss or gain). Bauman \& Currie (1980) reported that improvements in nutritional status of lactating cows resulted in changes in levels of plasma metabolites (i.e. glucose, lipids, amino acids, etc.) and an increase in the ratio of insulin to glucagon in the pancreas. These changes resulted in a greater hepatic uptake of metabolites, supporting the milk synthesis in the udder with the excess being diverted to peripheral circulation of cows. Such diversion of metabolites, occurring when the EB is improved in cows, increased the synthesis of glycogen in the liver, lipids in the adipose tissue and protein in the muscle, all together replenishing the postpartum body reserves and LW. In this study, the difference in postpartum LW in both parity groups can be attributed to changes in the somatotropic responses to the total nutrient and energy intakes from nutritional treatments in coordinating the mobilization/restoration of body mass as a physiological mechanism to adapt to the energy shortfall/excess, while sustaining milk production.

\section{Conclusion}

In this study, all cows mobilized their body reserves before and after calving. Compared with the control, HSLF and HSLF-LSHF treatments significantly decreased plasma NEFA and BHB levels in primiparous cows and increased plasma urea levels in both primiparous and multiparous cows. In addition, HSLF and HSLF-LSHF treatments significantly decreased postpartum LW loss of primiparous and multiparous cows in comparison to the control. These biological responses showed an enhanced nutritional status of dairy cows in HSLF and HSLF-LSHF treatments, benefiting the restoration of body reserves and LW, in comparison to the control. Further research is needed to investigate the point at which long-term changes in postpartum LW (i.e. LW loss $_{\text {nadir }}$ and number of days to reach the LW $_{\text {nadir }}$ ) act as stressors to disrupt milk responses, suppress the gonadotropic axis, and reduce fertility outcomes of dairy cows.

\section{Acknowledgements}

The authors express gratitude to the Western Cape Department of Agriculture (WCDA) for permission to use the facilities and data towards a PhD study for Mr Useni at the University of Stellenbosch. The support of the workers and management at the dairy section of the Elsenburg Research Farm is also greatly appreciated. This study was funded by the Western Cape Agricultural Research Trust (WCART) with technical support by the WCDA. Mr Useni acknowledges the financial support from the WCART towards his PhD studies.

\section{Authors' Contributions}

Conception and design of the trial: BAU and CJCM; data collection and statistical analysis: BAU; drafting of paper: BAU; critical revision: CJCM; final approval of version to be published: CWC.

\section{Conflict of Interest Declaration}

The authors certify that they have no affiliations with any organization or entity with any financial or non-financial interest in the subject matter or materials discussed in this manuscript.

\section{References}

Adewiyi, A.A., Gruys, E. \& Van Eerdenburg, F.J.C.M., 2005. Non-esterified fatty acids (NEFA) in dairy cattle: A review. Vet. Quarterly 27, 117-126. 
Alawneh, J.I., Stevenson, M.A., Williamson, N.B., Lopez-Villalobos, N. \& Otley, T., 2012. The effect of live weight change on reproductive performance in a seasonally calving, pasture fed dairy herd. Livest. Prod. 145, 131-139.

AOAC, 1990. Official methods of analysis, 14th ed. Association of official analytical chemists, Washington, DC, USA.

Bauman, D.E. \& Currie, W.B., 1980. Partitioning of nutrients during pregnancy and lactation: A review of mechanisms involving homeostasis and homeorhesis. J. Dairy Sci. 63, 1514-1529.

Bell, A.W., 1995. Regulation of organic nutrient metabolism during transition from late pregnancy to early lactation. J. Anim. Sci. 73, 2804-2819.

Broster, W.H. \& Broster, V.J., 1998. Body score of dairy cows. J. Dairy Res. 65, 155-173.

Buckley, F., O'Suilivant, K., Mee, J.F., Evans, R.D. \& Dillon, P., 2003. Relationship among milk yield, body composition, cow weight and reproduction in spring-calved Holsteins-Friesians. J. Dairy Sci. 86, 2308-2319.

Butler, W.R., 2003. Energy balance relationships with follicular development, ovulation and fertility in postpartum dairy cows. Livest. Prod. Sci. 83, 211-218.

Carlsson, J. \& Pehrson, B., 1994. The influence of the dietary balance between energy and protein on milk urea concentration. Experimental trials assessed by two different protein evaluation systems. Acta Vet. Scand. 35, 193-205.

Chagas, L.M., Bass, J.J., Blache, D., Burke, C.R., Kay, J.K., Lindsay, D.R., Lucy, M.C., Martin, G.B., Meier, S., Rhodes, F.M., Roche, J.R., Thatcher, W.W. \& Webb, R., 2007. Invited review: New perspectives on the roles of nutrition and metabolic priorities in the subfertility of high-producing dairy cows. J. Dairy Sci. 90, 4022-4032.

Chapinal, N., Carson, M., Duffield, T.F., Capel, M., Godden, S., Overton, M., Santos, J.E. \& LeBlanc, S.J., 2011. The association of serum metabolites with clinical disease during the transition period. J. Dairy Sci. 94, 4897-4903.

Coffey, M.P., Hickey, J. \& Brotherstone, S., 2006. Genetic aspects of growth of Holstein-Friesian dairy cows from birth to maturity. J. Dairy Sci. 89, 322-329.

Contreras, G.A. \& Sordillo, L.M., 2011. Lipid mobilisation and inflammatory responses during the transition period of dairy cows. Comparative Immun. Microbiol. Infect. Dis. 34, 281-289.

CPM-Dairy, 2006. Cornell Penn Miner Dairy Cattle Ration Analyser, Version 3.0.8, USA.

Drackley, J.K., 2000. Lipid metabolism. In: J.P.F D'Mello (ed) Farm animal metabolism and nutrition. CABI, London, U.K., pp. 97-119.

Drackley, J.K., Overton, T.R. \& Douglas, G.N., 2001. Adaptations of glucose and long-chain fatty acid metabolism in liver of dairy cows during the periparturient period. J. Dairy Sci. 84, E100-E112.

Drackley, J.K., Cicela, T.M. \& LaCount, D.W., 2003. Responses of primiparous and multiparous Holstein cows to additional energy from fat or concentrate during summer. J. Dairy Sci. 86, 1306-1314.

Esposito, G., Irons, P.C., Webb, E.C. \& Chapwanya, A., 2014. Interactions between negative energy balance, metabolic diseases, uterine health and immune response in transition dairy cows. Anim. Reprod. Sci.144, 60-71.

Evans, A.C.O. \& Walsh, S.W., 2012. The physiology of multifactorial problems limiting the establishment of pregnancy in dairy cattle. Reprod. Fertil. Dev. 24, 233-237.

Everitt, G.C., 1964. Maternal undernutrition and retarded foetal development in Merino sheep. Nature 201, $1341-1342$.

Garnsworthy, P.C., 2002. Fats in dairy cow diets. In: Recent advances in animal nutrition. Ed. Wiseman, J. \& Garnsworthy, P.C., Nottingham University Press, Nottingham, U.K., pp. 399-416.

Garnsworthy, P.C., Lock, A., Mann, G.E., Sinclair, K.D. \& Webb, R., 2008a. Nutrition, metabolism and fertility in dairy cows: 1. Dietary energy source and ovarian function. J. Dairy Sci. 91, 3814-3823.

Garnsworthy, P.C., Gong, J.G., Armstrong, D.G., Newbold, J.R., Marsden, M., Richards, S.E., Mann, G.E., Sinclair, K.D. \& Webb, R., 2008b. Nutrition, metabolism and fertility in dairy cows: 3. Amino acids and ovarian function. J. Dairy Sci. 91, 4190-4197.

Garnsworthy, P.C., Fouladi-Nashta, A.A., Mann, G.E., Sinclair, K.D. \& Webb, R., 2009. Effect of dietary-induced changes in plasma insulin concentrations during the early postpartum period on pregnancy rate in dairy cows. Reprod. 137, 759-768.

Gilmore, H.S., Young, F.J., Patterson, D.C., Wylie, A.R.G., Law, R.A., Kilpatrick, D.J., Elliot, C.T. \& Mayne, C.S., 2011. An evaluation of the effect of altering nutrition and nutritional strategies in early lactation on reproductive performance and oestrous behaviour of high yielding Holstein Friesian dairy cows. J. Dairy Sci. 94, 3510-3526.

Giron, H.C., 1973. Comparison between dry ashing and wet digestion in the preparation of plant material for atomic absorption analysis. Atom. Absorpt. Newsl. 12, 28-29.

Giuliodori, M.J., Delavaud, C., Chilliard, Y., Becú-Villalobos, D., Lacau-Mengido, I. \& De la Sota, L.R., 2011. High NEFA concentrations around parturition are associated with delayed ovulations in grazing dairy cows. Livest. Sci. 141, 123-128.

Goff, J.P. \& Horst, R.L., 1997. Physiological changes at parturition and their relationship to metabolic disorders. J. Dairy Sci. 80, 1260-1268.

Hammon, H.M., Stürmer, G., Schneider, F., Tuchscherer, A., Blum, H., Engelhard, T., Genzel, A. Staufenbiel, R. \& Kanitz, W., 2009. Performance and metabolic and endocrine changes with emphasis on glucose metabolism in high-yielding dairy cows with high and low fat content in liver after calving. J. Dairy Sci. 92, 1554-1566.

Jorritsma, R., Wensing, T., Kruip, T.A., Vos, P.L. \& Noordhuizen, J.P., 2003. Metabolic changes in early lactation and impaired reproductive performance in dairy cows. Vet. Res. 34, 11-26.

Lafontan, M., Sengenes, C., Moro, C., Galitzky, J. \& Berlan, M., 2009. Nutraceutic peptides and other lipolytic peptides involved in the control of lipid mobilization. In: G. Fruhbeck (ed). Peptides in energy balance and obesity. CABI, Oxfordshire, U.K., pp. 133-161.

Lammoglia, M.A., Willard, S.T., Hallford, D.M. \& Randel, R.D., 1997. Effect of dietary fat on follicular development and circulating concentrations of lipids and insulin on follicular development and circulating concentrations of lipids, 
insulin, progesterone, estradiol 17 $\beta, 13$, 14-dihydro-15-keto-prostaglandin $\mathrm{F}_{2 \alpha}$ and growth hormone in oestrous cyclic Brahman cows. J. Anim. Sci. 75, 1591-1600.

Lee, S.H. \& Hossner, K.L., 2002. Effects of propionate infusion on the expression of lipogenic genes and metabolic hormones in sheep. Animal sciences research report. Department of Animal Sciences, Colorado State University, Fort Collins.

Lemosquet, S., Rideau, N., Rulquin, H., Faverdin, P., Simon, J. \& Verite, R., 1997. Effects of duodenal glucose infusion on the relationship between plasma concentrations of glucose and insulin in dairy cows. J. Dairy Sci. 80 , 2854-2865.

Leroy, J.L.M.R., Vanholder, T., Van Knegsel, A.T.M., Garcia-Ispierto, I. \& Bols, P.E.J., 2008. Nutrient prioritization in dairy cows early postpartum: Mismatch between metabolism and fertility? Reprod. Dom. Anim. 43, 96-103.

Lucy, M.C., 2004. Mechanisms linking the somatotropic axis with insulin: Lessons from the postpartum dairy cow. Proc. N.Z. Soc. Anim. Prod. 64, 19-24.

Lucy, M.C., 2007. Fertility in high-producing dairy cows: Reasons for decline and corrective strategies for sustainable improvement. Soc. Reprod. Fertil. Suppl. 64, 237-254.

McArt, J.A., Nydam, D.V., Oetzel, G.R., Overton, T.R. \& Ospina, P.A., 2013. Elevated non-esterified fatty acids and $\beta$-hydroxybutyrate and their association with transition dairy cow performance. Vet. J. 198, 560-570.

Moallem, U., Kaim, M., Folman, Y. \& Sklan, D., 1997. Effect of calcium soaps of fatty acids and administration of somatotropin in early lactation on productive and reproductive performance of high producing dairy cows. J. Dairy Sci. 80, 2127-2136.

Moore, D.A. \& Varga, G., 1996. BUN and MUN: Urea nitrogen testing in dairy cattle. Compendium 18, $712-720$.

Oltner, R. \& Wiktorsson, H., 1983. Urea concentrations in milk and blood as influenced by feeding varying amounts of protein and energy to dairy cows. Livest. Prod. Sci. 10, 457-67.

Ospina, P.A., Nydam, D.V., Stokol, T. \& Overton, T.R., 2010a. Associations of elevated nonesterified fatty acids and beta-hydroxybutyrate concentrations with early lactation reproductive performance and milk production in transition dairy cattle in the north eastern United States. J. Dairy Sci. 93, 1596-1603.

Ospina, P.A., Nydam, D.V., Stokol, T. \& Overton, T.R., 2010b. Evaluation of nonesterified fatty acids and betahydroxybutyrate in transition dairy cattle in the north eastern United States: Critical thresholds for prediction of clinical diseases. J. Dairy Sci. 93, 546-554.

Overton, T.R. \& Waldron, M.R., 2004. Nutritional management of transition dairy cows: Strategies to optimize metabolic health. J. Dairy Sci. 87, E105-E119.

Pickett, M.M., Piepenbrink, M.S. \& Overton, T.R., 2003. Effects of propylene glycol or fat drench on plasma metabolites, liver composition and production of dairy cows during the periparturient period. J. Dairy Sci. 86, 2113-2121.

Ponter, A.A., Parsy, A.E., Saade, M., Mialot, J.P., Ficheux, C., Duvaux-Ponter, C. \& Grimard, B., 2006. Effect of a supplement rich in linolenic acid added to the diet of postpartum dairy cows on ovarian follicle growth and milk and plasma fatty acid compositions. Reprod. Nutr. Dev. 46, 19-29.

Reist, M., Erdin, D.K., Von Euw, D., Tschuemperlin, K.M., Leuenberger, H., Delavaud, C., Chilliard, H.M., Hammon, H.M., Kuenzi, N. \& Blun, J.W., 2003. Concentrate feeding strategy in lactating dairy cows: Metabolic and endocrine changes with emphasis on leptin. J. Dairy Sci. 86, 1690-1706.

Reynolds, C.K., 2006. Production and metabolic effects of site of starch digestion in dairy cattle. Anim. Feed Sci. Technol. 130, 78-94

Roche, J.R., Kay, J.K., Rius, A.G., Grala, T.M., Sheahan, A.J., White, H.M. \& Phyn, C.V.C., 2013. Immediate and deferred milk production responses to concentrate supplements in cows grazing fresh pasture. J. Dairy Sci. 96, 2544-2550.

Roche, J.R., Friggens, N.C., Kay, J.K., Fisher, M.W., Stafford, K.J. \& Berry, D.P., 2009. Body condition score and its association with dairy cow productivity, health and welfare. (Invited review). J. Dairy Sci. 92, 5769-5801.

Sakaguchi, M., 2009. Differences between body condition scores and body weight changes in postpartum dairy cows in relation to parity and reproduction indices. Can. Vet. J. 50, 649-653.

SAS, 2012. Statistical Analysis Systems (SAS Enterprise guide Software, Version 5.1). SAS ${ }^{\circledR}$ Institute Inc., Cary, North Carolina, USA

Schulz, K., Frahm, J., Meyer, U., Kersten, S., Reiche, D., Rehage, J. \& Dänicke, S., 2014. Effects of prepartal body condition score and peripartal energy supply of dairy cows on postpartal lipolysis, energy balance and ketogenesis: An animal model to investigate subclinical ketosis. J. Dairy Res. 81, 257-266.

Sears, P.M., Paape, M.J., Pearson, R.E. \& Gwazdaauskas, F.C., 1978. Comparison between tail vein and jugular vein cannulation in cattle. J. Dairy Sci. $61,974-979$.

Seifi, H.A., LeBlanc, S.J., Leslie, K.E. \& Duffield, T.F., 2011. Metabolic predictors of postpartum disease and culling risk in dairy cattle. Vet. J. 188, 216-220.

Senatore, E.M., Butler, W.R. \& Oltenacu, P.A., 1996. Relationships between energy balance and postpartum ovarian activity and fertility in first lactation dairy cows. Amin. Sci. 62, 17-23.

Staples, C.R., Burke, J.M. \& Thatcher, W.W., 1998. Influence of supplemental fats on reproductive tissues and performance of lactating cows. J. Dairy. Sci. 81, 856-871.

Tamminga, S., Luteijn, P.A. \& Meijer, R.G.M., 1997. Changes in composition and energy content of live weight loss of dairy cows with time after parturition. Livest. Prod. Sci., 52, 31-38.

Thorup, V.M., Edwards, D. \& Friggens, N.C., 2012. On-farm estimation of energy balance in dairy cows using only frequent body weight measurements and body condition score. J. Dairy Sci. 95, 1784-1793. 
Thorup, V.M., Højsgaard, S., Weisbjerg, M.R. \& Friggens, N.C., 2013. Energy balance of individual cows can be estimated in real time on farm using frequent live weight measures even in the absence of body condition score. Animal 10, 1631-1639.

Van Knegsel, A.T.M., Van den Brand, H., Graat, E.A.M., Dijkstra, J., Jorritsma, R., Decuypere, E., Tamminga, S. \& Kemp, B., 2007a. Dietary energy source in dairy cows in early lactation: Metabolites and metabolic hormones. J. Dairy Sci. 90, 1477-1485.

Van Knegsel, A.T.M., Van den Brand, H., Dijkstra, J., Van Straalen, W.M., Jorritsma, R., Tamminga, S. \& Kemp, B., 2007b. Effect of glucogenic vs lipogenic diets on energy balance, blood metabolites and reproduction in primiparous and multiparous dairy cows in early lactation. J. Dairy Sci. 90, 3397-3409.

Van Knegsel, A.T.M., Van den Brand, H., Dijkstra, J., Van Straalen, W.M., Jorritsma, R., Tamminga, S. \& Kemp, B., 2005. Effect of dietary energy source on energy balance, production, metabolic disorders and reproduction in lactating dairy cattle. Reprod. Nutr. Dev. 45, 665-688.

Van Straten, M., Shpigel, N.Y. \& Friger, M., 2008. Analysis of daily body weight of high-producing dairy cows in the first one hundred twenty days of lactation and associations with ovarian inactivity. J. Dairy Sci. 91, 3353-3362.

Van Soest, P.J., Robertson, J.B. \& Lewis, B.A., 1991. Methods for dietary fibre, neutral detergent fibre and non-starch polysaccharides in relation to animal nutrition. J. Dairy Sci. 74, 3583-3597.

Voigt, J., Gaafar, K., Hagemeister, H., Kanitz, W. \& Precht, D., 2003. Fat vs starch as energy sources in diets for high yielding lactating dairy cows. In: Progress in research on energy and protein metabolism, Ed. Souffrant, W.B. \& Metges, C.C., Rostock, Germany, pp. 445-448.

Walsh, S.W., Williams, E.J. \& Evans, A.C.O., 2011. A review of the causes of poor fertility in high milk producing dairy cows. Anim. Reprod. Sci. 123, 127-138.

Wankhade, P.R., Manimaran, A., Kumaresan, A., Jeyakumar, S., Ramesha, K.P., Sejian, V., Rajendran, D. \& Varghese, M.R., 2017. Metabolic and immunological changes in transition dairy cows: A review. Vet. World 10, 1367-1377.

Wathes, D.C.; Cheng, Z.; Bourne, N.; Taylor, V.J.; Coffey, M.P. \& Brotherstone, S., 2007. Differences between primiparous and multiparous dairy cows in the inter-relationships between metabolic traits, milk yield and body condition score in the periparturient period. Domest. Anim. Endocrinol. 33, 203-225. 